\title{
The Concept and Characteristics of Public Enterprises in Ethiopia: An Overview
}

\section{Abstract}

Tewodros Meheret *

The role of public enterprises in Ethiopia is manifested in the quantum of capital they command and the magnitude of the economy's dependence on such enterprises. Essential services such as electricity, telecommunication, shipping and logistics, transport and the like are mainly, if not solely, provided by public enterprises. Owing to the dearth of research on the subject, there is the need for conceptual clarity on the notion and the legal forms (or designations) of such enterprises. Leafing through the relevant laws, one encounters many definitions. Moreover, the form or designation of public enterprises and the diversity of the legislation applicable thereof necessitate inquiry into the concept and their characteristics.

\section{Key words}

Public economic enterprise, Public enterprise, Company, Corporation, Ethiopia

DOI http://dx.doi.org/10.4314/mlr.v8i2.3

\section{Introduction}

The state has a public purpose in the exercise of its sovereign power. Such power is inherent in statehood and justifies the existence of a government. That is primarily manifested in the specific function of governments in discharging their traditional role of ensuring peace and security. But any modern state assumes responsibility beyond its traditional function of maintaining peace and order and protecting the country from external aggression, and it engages in economic activities. To accomplish this, one of the options is setting up an entity that undertakes commercial activities.

\footnotetext{
* LL.B, LL.M, Lecturer and Attorney-At-Law, Addis Ababa University, School of Law. The author can be reached at tmeheret@yahoo.com
} 
Such enterprises have become a universal phenomenon in all contemporary societies. ${ }^{1}$

However, the reason why and the extent to which such a role is assumed varies depending on the political economy or ideology of a state. It is common to find enterprises owned by the state in different countries despite variation in their ideologies. ${ }^{2}$ Yet, this does not render ideology irrelevant as the utility they will have in a country is a function of the political, economic and philosophical underpinning of the legal system. Therefore, the question concerns the allowable limit of direct government activity in the market. ${ }^{3}$

This article discusses 'public enterprise' as a concept from the standpoint of Ethiopian law. Because of ambiguities in the various laws and due to the diversity of forms (or designations) utilized, it has become difficult to clearly identify what exactly the term 'public enterprise' refers to. Some prefer to use the term 'public economic enterprises' so that the scope becomes broad enough to include other forms through which the state is engaged in economic activities. The first section of this article introduces the concept and highlights the ambiguities in the use of the term. The second section briefly deals with the salient features of a public enterprise so that the multiplicity of definitions can be handled with due caution. The third section explores the different forms of economic enterprises (that are set up to carry out commercial activities) with a view to bringing to light the diversity of form and its implications. The fourth section spells out the raison d'être of such enterprises, followed by the last section which briefly continues discussing the theme in the Ethiopian context.

\section{Defining the term 'public enterprise'}

Nomenclature is part of the discourse on public sector enterprises which has been the source of ambiguity. ${ }^{4}$ In Ethiopia, one of the major proclamations

\footnotetext{
${ }^{1}$ Law and Public Enterprises in Asia (1976), International Legal Center, (Praeger Publishers), p. v.

${ }^{2}$ For instance, we can mention the Tennessee Valley Authority of the USA and you may call to mind state owned corporations of China.

${ }^{3}$ Owen E. Hughes (1998), Public Management and Administration, (Palgrave Macmillan), p. 1.

${ }^{4}$ Kauzya John-Mary(2005), The Question of the Public Enterprise and Africa's Development Challenge: a Governance and Leadership Perspective, p. 4, Paper presented during the Ad hoc Expert Group Meeting on "Re-inventing Public Enterprises" held in New York from 27 to 28 October 2005, available at
} 
on public enterprises defines the word 'enterprise' while other laws use the term 'public enterprise'. It may be inquired whether the law uses the term "enterprise" differently from the word "public enterprise". But, the body of the definition clarifies the potential confusion by describing it as a public enterprise. Despite the multiplicity of terminologies in the proclamation, they conceptually refer to the same thing as can be gathered from other laws as well.

The need for a definition is not only academic for it has far reaching practical ramifications. Apart from ensuring conceptual clarity and delimiting the boundaries of the notion, the need to define public enterprise is felt practically in circumstances when the Auditor General's exercise of power requires recognition of entities as public enterprises. Where the law empowers a body to audit them, or when Parliament exercises its power to review performance or a regulatory organ, it is essential to distinguish the entities that come under such a law.

Moreover, the enjoyment of rights and the assumption of responsibilities (such as investment incentives, privileges, rights and criminal liability of their officers) that are specifically applicable to public enterprises require marking out the entity. For instance, the definition of the term in criminal law has the purpose of creating liability on the officials of such enterprises under certain circumstances. Identifying such enterprises is also essential for economic decision making and statistical data on the size of the public sector with a view to analyzing economic implications and other issues. The same applies to the pursuits of developing policy, strategy and planning, and undertaking comparative research studies. ${ }^{5}$

Unlike other similar enterprises such as business organizations, the attempt to distinguish an entity that can be regarded as a "public enterprise" may present challenges analogous to abstract concepts. ${ }^{6}$ Several reasons explain why it is difficult to define the term. Some of the reasons include the highly elastic nature of the concept, its contingency on local environments, the convergence of both public and enterprise aspects in a single entity ${ }^{7}$ and

< http://unpan1.un.org/intradoc/groups/public/documents/un/unpan021612.pdf>, (accessed on 07/08/2014).

5 See V.V. Ramanadham (1984), The Nature of Public Enterprise (St. Martin's Press) p. 61-63.

${ }^{6}$ Ibid, p. 63.

7 Praxy Femandes and Pavle Sicherl (1981), Seeking Personality of Public Enterprises, (International Center for Public Enterprises in Developing Countries) P. 16-17. 
the need to make it conceptually and operationally satisfactory. ${ }^{8}$ It is also suggested that the variation in definitions are informed by ideology, values, interests, dispositions and circumstances that bring public enterprises into existence. $^{9}$

The most effective and logical way of formulating a definition would be to identify the essential characteristics and the dependent and independent variables affecting the "public enterprise". ${ }^{10}$ Generally, the term public enterprise refers to enterprises established under the ownership of the state or public authorities. However, the particular features of such enterprises are not the same in all definitions. For instance, International Center for Public Enterprises has adopted the following definition:

Any commercial, financial, industrial, agricultural or promotional undertaking - owned by public authority, either wholly or through majority shareholding - which is engaged in the sale of goods and services and whose affairs are capable of being recorded in balance sheets and profit and loss accounts. Such undertakings may have diverse legal and corporate forms, such as departmental undertakings, public corporations, and statutory agencies, established by Acts of Parliament or Joint Stock Companies registered under the Company Law. ${ }^{11}$

This definition is broad enough to embrace all forms of public economic enterprises established across countries and ideologies. However, it does not hold true in all legal systems because of the peculiar factors of a country may prompt a definition that fits the setting. For example, the law governing public enterprises (Public Enterprises Proclamation No. 25/1992) through which the transition from command to market economy was realized in Ethiopia by transforming the role of public enterprises defines it as "a wholly state owned public enterprise established pursuant to the same Proclamation to

\footnotetext{
${ }^{8}$ Supra note 5 , p. 63.

${ }^{9}$ D. O. Adeyemo and Adeleke Salami (2008) A Review of Privatization and Public Enterprises Reform in Nigeria, Contemporary Management Research, Vol. 4, No. 4, December 2008 p. 402, also <available at www.cmrjournal.org/article/download/607/2280>

${ }^{10}$ Supra note 7, p. 18.

${ }^{11}$ Prahlad K. Basu (2005), "Reinventing Public Enterprises and Their Management as the Engine of Development and " in Growth Public Enterprises: Unresolved Challenges and New Opportunities, United Nations, p. 10.
} 
carry on for gain manufacturing, distribution, service rendering or other economic and related activities."1

This definition embodies three basic elements that determine the feature of a public enterprise. The first element relates to ownership and requires an enterprise to be wholly owned by the state so that it can be characterized as a public enterprise. Hence, mere existence of public investment share in an enterprise does not suffice (irrespective of its percentage) unless the government is the sole owner. The law excludes enterprises in which we find joint investment of the two sectors, namely, private and public, irrespective of the quantum of the investment.

The second element requires establishment under the proclamation. The proclamation sets the legal framework for entities established by the State for the purpose of economic activities for gain. The requirements for their formation, operation, structure, and exit are embodied in the proclamation. The government's act should indicate that the entity established is governed by this legislation ${ }^{13}$ if it is a public enterprise. The third element in the definition of 'public enterprise' under Proclamation No. 25/1992 is the purpose of the entity which distinguishes it from the main function of the State. Public enterprises are commercial entities as distinguished from administrative agencies which carry out regulatory activities and render public service.

Subsequent to this definition, several proclamations have come up with diversified usages of this term. The first modification is introduced ${ }^{14}$ by Privatization of Public Enterprises Proclamation No. 146/1998 which states: "enterprise means a public enterprise governed by the Public Enterprises Proclamation No. $25 / 1992$ or an establishment designated by the

12 Public Enterprises Proclamation No. 25/1992, Negarit Gazeta, $51^{\text {st }}$ year, No. 21(Hereinafter referred to as Proc. No. 25/1992), Art. 2(1); Its predecessor defines the term as "any public enterprise established by regulations issued pursuant to this proclamation. Article 2(2) Public Enterprises Public Enterprises Proclamation No. 20/1775 (Negarit Gazeta 34th year, No. 15February 4, 1975); See also Regulations No. 5/1975 (Negarit Gazeta $34^{\text {th }}$, year, No. 31, June 4, 1975).

13 Public Enterprises Proclamation No. 25/1992, Article 6(2)..

${ }^{14}$ In fact, earlier the term was defined in Proc. No. 17/1996 Establishment of Board of Trustees for privatized public Enterprises, but in connection with privatized public enterprises as "Enterprise" means a public enterprise established under Proclamation No. 25/1992 or under a similar legislation and privatized pursuant to the Ethiopian Privatization Agency Establishment Proclamation No. 87/1994, or a branch thereof. 
Government as a public enterprise for the purpose of the application of the this Proclamation." 15

Accordingly, there can be undertakings which the Government may classify as public enterprises for the purpose of privatization. This definition does not seem to have the objective of broadening the scope of the term as the limb added is meant to designate some entities as public enterprises for the purpose of the proclamation, i.e., privatization. Although the use of the term is broader as compared to the meaning embodied in Proc. No. 25/1992, it does not change the content of the definition for the purpose of the public enterprise proclamation. It simply denotes that for the purpose of privatization some entities may be considered as public enterprises.

Proc No. 412/2004 further offers another definition which considers public enterprise as an enterprise as defined under Article 2(1) of the Public Enterprises Proclamation No. 25/1992, or as a wholly state-owned share company. But it excludes those enterprises for which specific supervising authorities are designated by other laws or decisions of the Government. ${ }^{16}$ As compared to the definitions discussed in the preceding paragraphs, this is narrower as it excludes some public enterprises, and it is meanwhile broader because it extends the application of the term to share companies wholly owned by the state.

It can be argued that the Proclamation amended the requirement of total state ownership which was one of the elements under Proclamation No. 146/1998 and Proclamation No. 277/2002. ${ }^{17}$ However, this definition is incorporated in a proclamation issued to establish an authority and the purpose of the definition is to identify the enterprises that come under the supervision of this administrative agency. In addition to the absence of explicit repeal in it, Proclamation No. 412/2004 clearly makes reference to Proclamation No. 25/1992. One can thus conclude that Proc No. 412/2004 does not have the purpose of amending Proclamation No. 25/1992 in this regard. Yet, according to one of the cardinal principles of interpretation, the latter legislation prevails over the former, and the latest and prevailing intention of the legislator is expressed in the most recent legislation. The

15 Privatization of Public Enterprise Proclamation No. 146/1998, Federal Negarit Gazeta, $5^{\text {th }}$ Year, No. 26, Article 2(3).

${ }^{16}$ Privatization and Public Enterprises Supervising Authority Establishing Proc. No. 412/2004 Federal Negarit Gazeta 10 ${ }^{\text {th }}$ year, No. 57 (Hereinafter Proc No. 412/2004).

${ }^{17}$ Getahun Seifu, "Revisiting Company Law with the Advent of ECX", Mizan Law Rev., Vol. 4(1), p. 111. 
application of the principle presupposes that simultaneous application of the two is impossible because of the ensuing contradiction.

The two definitions have two distinct goals. Proclamation No. 25/1992 is an overarching proclamation applicable to any public enterprise irrespective of the supervising authority designated. On the other hand, as indicated above, the objective of the definition in Proclamation No. 412/2004 is to identify those entities which are supervised by the authority. However, the enterprises which fall outside the scope of Proclamation No. 412/2004 are still public enterprises under Proclamation No. 25/1992. ${ }^{18}$ Even though these enterprises are not governed by Proclamation No. 412/2004, a different supervising authority is named thereby enabling them to fall under the definition articulated under Proclamation No. 25.1992. In other words, the definition given in Proclamation No. 412/2004 has no intention of identifying public enterprises per se, but merely selects those enterprises which will be governed by that particular proclamation or supervised by Privatization and Public Enterprise Supervising Authority.

What is peculiar about Proclamation No. 412/2004 is that it introduced a new form of public enterprise (i.e. state-owned share company) that was not recognized under Proc. No. 25/1992. Hence, share companies owned by the state are considered as public enterprises under Proclamation No. 412/2004 even if, for legal and practical purposes, they are business organizations by and large regulated by the Commercial Code. Yet, the share companies referred to herein are different from business organizations recognized as such by the Commercial Code.

For the purpose of this particular law, reference is made to "a share company partially owned by the state, but excluding those share companies in which the state owns shares through public enterprises". ${ }^{19}$ It mainly encompasses companies created by conversion of public enterprises into share companies. In fact, this is a temporary situation by which privatization is facilitated as can be drawn from article 5(1) and 5(4) of Proclamation No. 146/1998. It is a solution to fill the gap created between conversion and privatization of a public enterprise. However, the transition could, for various reasons, take longer time than anticipated. Despite the categorization of certain share companies into public enterprises (in Proc. No. 412/2004),

18 This can be clearly understood from article 14 of proclamation No. 412/2004 which uses the term public enterprise to refer to those which are excluded. It is explicit that the definition is for the purpose of determining the scope of supervisory power of Privatization and Public enterprises Supervising Authority.

19 Proc. No. 412/2004, Article 2(3). 
they are subject to different legal regimes thereby confirming that the term "public enterprise" has retained the meaning ascribed to it under article 2(1) of Proclamation No. 25/1992.

Subsequent laws came up with an array of definitions which kept on introducing additional elements broadening the scope of the term. Article 2(4) of the Revised Federal Ethics and Anti-Corruption Commission Establishment Proclamation No. 433/2005 defines the term as "any Federal Public Enterprise or Share Company the ownership of which is fully or partly owned by the Government." For the Criminal Code, it is "a Federal or Regional Government enterprise or share company, in which the Government has total or partial share as an owner". ${ }^{20}$

In line with the federal state structure, Art. 2(21) of Trade Practice and Consumers' Protection Proclamation No. 685/2010 21 and Article 2(3) of the Commercial Registration and Business Licensing Proclamation No. 686/2010 classify public enterprises into federal and regional. According to these proclamations, a business organization whose shares are totally owned by the federal government or a public enterprise established by a regional state are deemed to be a public enterprise. Likewise, Article 2(10) of Investment Proclamation No. 769/2012 defines the term as an enterprise, partially or wholly owned by the federal or regional government established to engage in production, distribution, service rendering or related economic activities in the form of commerce.

One of the tasks of the Office of the Auditor General is to audit or cause to be audited the accounts of the federal government offices and organizations. ${ }^{22}$ According to Article 2 of Proclamation No. 669/2010, the term government "organization" means any production, distribution, service rendering, regulatory or any other trading organization wholly or partially owned by the federal government. ${ }^{23}$ In light of this proclamation and the laws highlighted in the preceding two paragraphs, it can be observed that there is a new element added in the definition of a public enterprise by

${ }^{20}$ Art. 402(3) The Criminal Code of Ethiopia Proclamation No.414/2004, $9^{\text {th }}$ May 2005. Addis Ababa.

${ }^{21}$ It is interesting to note that the definition is omitted in the new proclamation (Trade Competition and Consumers Protection Proclamation No. 813/2013) which repealed proclamation no 685/2010.

${ }^{22}$ Office of the Federal Auditor General Establishment /Amendment/ Proclamation No. 669/2010, Article 5.

${ }^{23}$ Office of the Federal Auditor General Establishment /Amendment/ Proclamation No. 669/2010. Article 2. 
including enterprises which are partially owned by the state. Moreover, distinction is made between enterprises which may be established by the federal and state governments.

It can generally be noted that the above definitions share features that expressly mention or impliedly incorporate the definition of public enterprises embodied in Proclamation No. 25/1992. However, there are additions and exclusions introduced by each proclamation, and the elements which distinguish one definition from the other are diverse. Proclamation No. 25/1992 was enacted at the time when the form of state structure was unitary, and the concept of regional public enterprise is brought up later on along with Ethiopia's current federal structure.

It should be noted that the foregoing analysis is for the most part based on laws applicable to enterprises set up by the Federal government. Regional states can also establish enterprises for the purpose of carrying out commercial activities. ${ }^{24}$ Hence, in understanding the concept, it is imperative to take into account the role of public enterprises established by regional states, as well. However, owing to the absence of a legal framework or due to the diversity of laws governing such enterprises in regional states, a comprehensive definition (that can be applicable to all) is lacking.

The share of ownership is also another source of diverse definitions. The question whether public enterprises are characterized by total or partial state ownership (even under settings of majority holding) is answered differently under various laws. For some scholars and jurisdictions, majority holding in a commercial entity suffices to consider it as a public enterprise. For others, full ownership or the form of the entity is an imperative factor.

The form of an economic entity (corporation, share company, public enterprise) entails diverse outcomes regarding its status depending on the definition that is pursued. The diversity in definition thus insinuates a chaotic situation in the legal regime on public enterprises as every legislation comes up with its own definition of the term thereby rendering it practically impossible to ascribe a distinct meaning to the term. Thus, one has to be specific as to which context or subject matter or legislation he/she is referring to if the term is to have a meaning in the midst of prevailing

${ }^{24}$ For instance, Oromia Regional State established Arsi Forest Enterprise and Bale Forest Enterprise under Regulation No. 86/2007 and Regulation No. 88/2007 respectively ; Amhara regional State formed the Amhara Seed Enterprise, pursuant to Council of Regional Government Regulation No. 66/2009; Hareri Regional State established Government Houses Administration Enterprise under Proclamation no. 16/1991. 
ambiguities and inconsistencies. These challenges in interpretation thus call for closer examination into the characteristics of public enterprises.

\section{Characteristics}

A public enterprise is necessitated by the need "to find an effective and efficient economic organization under socially satisfying conditions." 25 Hence, the economic and social aspects converge in a single entity. It is a borderline entity sharing the features of a public entity and business. A public enterprise combines dual features (in status and functions) as enterprise aiming at profit while at the same time having public nature as a public entity.

It is proposed that the most effective methodology for identification is to specify the tests which need to be met if an institution can properly be identified as a public enterprise. To this end, certain tests can be employed, namely: ownership test, public purpose test, the field of activity test, the concept of investment and return, the concept of marketing and the commercial accounts. These tests are believed to enable us conceptualize the notion of public enterprises and have a better understanding of the entity based on its features. ${ }^{26}$

\subsection{Public Dimension}

The ascertainment of the public dimension in the realms of ownership, purpose or otherwise, is recurrent in the discourse on public enterprises. Public enterprises are singled out as part of the broader stream of the public sector. ${ }^{27}$ Hence, questions may be posed as to what makes a purpose public or how public are public enterprises. The term "public" can mean accessibility and benefit to the general public, ownership by the public, or ownership and control by public authorities. With regard to public

${ }^{25}$ Pavlve Sicherl (1981), "Concepts of Public Enterprise in Different SocioEconomic Systems" in Praxy Femandes and Pavle Sicherl (ed.), Seeking Personality of Public Enterprises (International Center for Public Enterprises in Developing Countries), p. 80.

${ }^{26}$ Praxy Femandes(1981) "Public Enterprise-A Word and A Vision" in Praxy Femandes and Pavle Sicherl(ed.), Seeking Personality of Public Enterprises(International Center for Public Enterprises in Developing Countries), p. 98-99.

27 Supra note 7, p. 16. 
enterprises, it is ownership by public authorities which stands out even though that is not the only factor which determines the status of the entity. ${ }^{28}$

It is necessary to identify the features which bestow on it public character. There is no consensus on the elements which fairly describe the public aspect of enterprises. For some, it is non-private accretion of net benefit, public decision making and social accountability which primarily stand out. ${ }^{29}$ For others, the critical factor is the question of public purpose. ${ }^{30}$ At any rate, in the absence of consensus on the factor which fundamentally establishes the 'publicness' of a public enterprise, we can select some essential factors as highlighted below.

\section{a) Public ownership.}

One manifestation of the public dimension of public enterprises is that they are owned by the public. Sometimes distinction is made between ownership in the legal sense as a formal claim in the framework of the legal order and ownership in the economic sense which inquires into the actual beneficiary from the thing. ${ }^{31}$ The public is presumed to exercise the ownership through the state, the government, local authorities or municipalities. The word "public" is therefore used as " of or pertaining to the people, relating to or belonging to, or affecting a nation, state or community at large; as opposed to private". ${ }^{32}$ Obviously, an enterprise becomes public if it is wholly owned by public authorities. In other words, there will usually be no doubt about the nature of an entity if ownership exclusively belongs to a public authority. $^{33}$ In this regard, Proclamation No. 25/1992 is explicit and considers as public only those which are wholly owned by the state.

${ }^{28}$ Supra note 7, p. 18.

${ }^{29}$ Supra note 4, p. 14.

${ }^{30}$ Supra note 7, p. 18.

${ }^{31}$ Supra note 25, p. 85 . The distinction has been said to be important to study the potential and actual impact and orientation of public enterprises.

32 Ibid; Identification of the owner is not that easy. It is inquired whether the owner is the legislature, the executive, workers, consumers or capital providers. See Tansu Ciller(1981)," "Classification and Taxonomy of Public Enterprise-An Explanatory Perspective" in Praxy Femandes and Pavle Sicherl(ed.), Seeking Personality of Public Enterprises(International Center for Public Enterprises in Developing Countries), p. 186.

33 A glance at Ethiopia Commodity Exchange Proclamation No. 550/2007 (Federal Negarit Gazeta, $13^{\text {th }}$ Year No. 61) reveals that this is subject to an exception. The Ethiopia Commodity Exchange is established as a wholly state owned market institution having its own legal personality to which a supervising authority is designated. But it is not a public enterprise if we apply the definition of Pro. No. 
However, public ownership of enterprises becomes ambiguous when ownership is not full. Ownership may vary "along a continuum from zero to one-hundred percent presenting" a challenge to specify the cut-off point which distinguishes public from private enterprises. ${ }^{34}$ A predicament may thus arise regarding enterprises that are only partly owned by a public authority as in the case of joint investment or ventures. In the different laws which define the term, we have seen that although ownership is an essential element, the extent of public investment is not resolved. It is assumed that a majority shareholding by a public authority makes the enterprise a publicly owned. According to this view, an entity becomes a public enterprise if it is owned by public authorities, central, state or local, to the extent of $50 \%$ (fifty percent) or more as that ensures managerial control. ${ }^{35}$

From the various definitions examined above, we can observe that certain proclamations merely require the existence of public share in an investment to consider it public. However, it may be inquired whether an enterprise in which the stake of the government is less than private contribution and consequently with reduced financial stake and control can be considered as a public enterprise.

It can be argued that an entity with minority governmental shareholding may still be regarded as a public enterprise depending on whether the other elements of the public dimension are present. Accordingly, it is submitted that with adequate measure of public control and public management, an enterprise becomes public even if the government has minority holding. ${ }^{36}$ What if the minority holding is devoid of any other characteristic of a public entity? In response to such challenges, some suggest that the ownership boundary should be set at 50 percent $^{37}$ which appears to be the logical way

$25 / 1992$ as it is not stated in the establishing proclamation (ignoring the fact that it is not established by a regulation as required under proc. No. 25/1992) that it is governed by the same. But it becomes a public enterprise pursuant to the definitions adopted lately since partial investment by the state suffices to treat an entity as a public enterprise.

${ }^{34}$ Leroy P. Jones(1981), "Definition and Taxonomy of Public Enterprise" in Praxy Femandes and Pavle Sicherl (ed.), Seeking Personality of Public

Enterprises(International Center for Public Enterprises in Developing Countries), p. 124.

${ }^{35}$ Supra note 7, p. 24.

${ }^{36}$ Supra note 7, p. 19.

${ }^{37}$ Supra note 3, p. 125. In India in a public enterprise holding of the government is more than 50\%. See P.K. Jain, Seema Gupta, Surendra S.Yadav (1914), Public 
of determining the public aspect of such enterprises based on the stake of the government.

We can also inquire into the effect of indirect ownership. Where a fully state owned public enterprise acquires majority holding in a newly formed enterprise, or if two public enterprises that are fully owned by the government set up an enterprise, the question becomes whether indirect ownership by the sate confers public character on the new entity. In such cases, the government is the indirect source of finance. Yet, one of the laws which extend the application of the term to partial public ownership, excludes (from the definition) those share companies in which the state owns shares through public enterprises. ${ }^{38}$ Distinction is often made between ownership by the Government and ownership of public enterprises which are autonomous and independent legal persons. Even though the Government ultimately owns the net assets of such enterprises, it is doubtful to conclude that what is owned by the enterprises is owned by the state. One can thus argue that ownership should be limited to direct ownership by the state, the government, or local authorities.

\section{b) Public purpose}

A public enterprise has multiple purposes, including public purpose. The designation of purpose is one of the conceptual differences between public and private enterprises. In particular, the impact of the activities of the enterprise on the society is an essential element of the distinction. The goals of public enterprises emanate from the state and the society and are meant to attend to public purpose. But public purposes enunciated by public enterprises to some extent depend on value judgment in addition to preferences of functions assigned to the enterprises. ${ }^{39}$

Moreover, the role of public enterprises hinges on the role and nature of the state which in turn depends on economic and political considerations. Ideally, the state may be considered as representative of the people, which will administer public enterprises on behalf of the latter. However, in reality, it may become an agent of the ruling class or group or interest groups. Thus, it is argued that the state may not define public purpose in such a way that the public enterprise would serve the interest of the people as a whole. ${ }^{40}$

Sector Enterprises in India: The Impact of Disinvestment and Self Obligation on Financial Performance( Springer India), p. 7.

${ }^{38}$ Proc. No. 412/2004, Article 2(3).

${ }^{39}$ Supra note 25, pp. 79-80.

${ }^{40}$ Supra note 25, p. 81. 
The establishment of a public enterprise usually presupposes the attainment of some public policy goals. The rationale for setting up these enterprises is that they are better instruments for promoting developmental goals. This could be reflected in the corporate objectives of or the allocation of resources in an enterprise. For instance, one of the purposes of EthioTelecom is "to engage, in accordance with development policies and priorities of the government, in the construction, operation, maintenance and expansion of telecommunications networks and services. ${ }^{, 41}$ Unlike ordinary enterprises, the priority is set by the government irrespective of economic returns and prudent business practice. Ethiopian Grain Trade Enterprise, inter alia, aims at the stabilization of markets for farmers' produces so that they will be encouraged to increase their outputs. ${ }^{42}$ These objectives may not be profitable in business terms. However, the idea is that the public benefits from the realization of the objectives.

Unlike a private business, profit is not the only motive that drives the enterprise or its decisions. It has public purpose to achieve such as employment, public service, access, fair distribution, economic development, and other elements of public interest. However, the question remains whether they are supposed to cater for a particular public purpose though it could threaten the commercial existence of the enterprise. This issue was raised when Ethiopian Grain Trade Enterprise submitted its report to a committee of the Council of Peoples' Representative. In response to a query posed by the committee, it was argued that stabilizing the market cannot be

${ }^{41}$ Ethio-Telecom Establishment Council of Ministers Regulations No. 197/2010, (Federal Negarit Gazeta, $17^{\text {th }}$ Year, No. 11), Article 5(3).

42 Ethiopian Grain Trade Enterprise Re-establishment Council of Ministers Regulations No. 58/1999, Art. 5(2). At a parliamentary hearing, the enterprise maintained that it have no duty to stabilize the market in response to the criticism that $\mathrm{t}$ it has no grain in its store to be used for stabilizing the market. See Reporter Amharic 17 November 2013, <http://www.ethiopianreporter.com/>; In developing countries where social expectations are often are articulated through national economic development plans, the operative assumption is that a state enterprise should promote the strategies and priorities contained in national economic development plans. Where there is a conflict between the plan and corporate self-interest, a state corporation must compromise its self-interest in order to foster development. A state enterprise should not object to this, even if its earnings are reduced, since it is under a duty to benefit its public shareholder. See Robert Fabrikant (1976), Developing Country State Enterprises: Performance and Control, Colum. J. Transnat'l L. Vol. 15, p. 49. 
undertaken unless the government guarantees to make up for the imminent $\operatorname{loss}^{43}$ incurred by the Enterprise.

\section{c) Public Control and Management}

Government's inherent power enables it to exercise control on private or public enterprises. However, the control it has over public enterprises as an owner is internal control which involves "agent-principal" relationship between the government and the enterprise. ${ }^{44}$ As enterprises are controlled by persons who have made the investment, government control over public enterprises is primarily practiced through its power to appoint top management. ${ }^{45}$

A public enterprise is controlled and managed by the owner, i.e. the relevant public authority. Accordingly, one of the items to be stated in the establishing legislation is the name of the supervising authority ${ }^{46}$ which protects and promotes the interest of the public in the enterprise. The designated public authority is responsible to appoint and remove the members of the board who are empowered to appoint and direct the management of the enterprise. ${ }^{47}$ It also appoints external auditors, approve financial reports of the enterprise and external audit reports and approve the investment plan of the enterprise submitted to it by the Board. ${ }^{48}$ It is through these tools that public authorities control public enterprises.

\subsection{Private Dimension}

The dual nature of a public enterprise gives it the features of a business enterprise, as well. The entity preserves its public features without at the same time undermining its enterprising dimension. The reason why a government opts to set up the entities in this form is to enable them operate as business entities. They operate in the same manner as private enterprises engaged in commercial activities. Thus, they have the following attributes.

\section{a) Commercial Nature}

Public enterprises are formed to undertake manufacturing, distribution, service rendering or other economic and related activities with a view to selling goods and services. These activities are undertaken for gain with a

\footnotetext{
${ }^{43}$ News item which appeared in the Reporter Amharic, 17 November 2013

${ }^{44}$ Supra note 34, p. 127.

${ }^{45}$ Ibid.

${ }^{46}$ Proc . No. 25/92, Article 6(9).

${ }^{47}$ Proc 25/92 Article 11(1).

${ }^{48}$ Proc 25/92 Article 11(6), 9, 10.
} 
view to ensuring that there is return on investment. This confers on them "commercial nature" making them subject to the rules of the market. Their commercial character is manifested in different forms. First, a business enterprise cannot engage in trade activities without registration in the commercial register. ${ }^{49}$ Accordingly, a public enterprise is required to register in the commercial register of the Federal government or a regional state as the case may be. ${ }^{50}$ It also needs to have business license to carry out the commercial activities stated in the establishing regulation. ${ }^{51}$

Second, persons "bring together contributions for the purpose of carrying out activities of an economic nature and participate in the profit and losses arising from the commercial activity" ${ }^{52}$ On the other hand, the government puts resources at the disposal of the enterprise it establishes, after which the enterprise is expected to sustain and develop itself through its profit. After its establishment, a public enterprise obtains its income from its economic activities and through the charges paid by users. This distinguishes public enterprises from administrative authorities which receive annual budget allocations from the State. A public enterprise must be viable so that it can remain in the market. That is why the law makes it a ground for dissolution if a public enterprise loses $75 \%$ of its capital ${ }^{53}$. It is also to be noted that a public enterprise may encounter bankruptcy if it suspends payment. ${ }^{54}$ Its survival thus depends on economic viability at least to the threshold of maintaining its capital.

The third manifestation of a public enterprise's private dimension relates to its competitiveness in the market. Any business entity markets its output whereas a public service institution provides these outputs free of charge. ${ }^{55}$ Even though public enterprises address social purposes, they cannot survive unless there are schemes that make up for the loss sustained while undertaking unprofitable activities. These enterprises should thus either set the price of goods or services based on the market, or losses must be

49 Commercial Registration and Business Licensing Proclamation No. 686/2010, (Federal Negarit Gazeta, $16^{\text {th }}$ Year, No. 42), Art. 6(1).

${ }^{50}$ Ibid, Art. 7(10),(11), Article 14.

${ }^{51}$ Ibid, Art. 32(1), (6).

52 Commercial Code of Ethiopia Proclamation No. 166 of 1960, (Negarit Gazeta, Gazette Extraordinary, 19th Year, No. 3, Addis Ababa, 5the May, 1960), Art. 211.

${ }^{53}$ Proc. 25/1992, Art. 39(4).

${ }^{54}$ Proc 25/1992, Art. 40.

55 Supra note 7, p. 21. 
shouldered by the State. The mere fact that they are organized as public enterprises demands that they set price based on the market unless the government decides to subsidize the enterprise as in the case of certain public utilities.

\section{b) The accounting concept}

Public enterprises and other government institutions are subject to different accounting systems. The establishment of a public enterprise is contingent upon its capital which is indispensable for its existence. ${ }^{56}$ Moreover, its capital serves as security for its creditors because of its limited liability. ${ }^{57}$ Owing to its commercial nature, the law requires it to maintain two books of account, i.e., a balance sheet and a profit and loss account. It should also follow generally accepted accounting principles in maintaining financial records and preparing financial documents. ${ }^{58}$

A public enterprise is required to close its accounts at least once a year. The annual closing of accounts shall be completed within three months following the end of the financial year. ${ }^{59}$ Unlike other public entities which utilize their annual budget, an enterprise shall pay to the Government dividend within seven months following the end of the financial year. ${ }^{60}$ The relevant laws concerning taxes and duties are applicable to enterprises ${ }^{61}$ sometimes raising the issue whether the government should tax itself. The accounts of each enterprise shall be audited by external auditors appointed by the supervising authority. ${ }^{62}$ All these duties are incidental to the commercial aspect of public enterprises which are not imposed on other government institutions.

\section{Forms of Public Economic Enterprises}

In this section, we use the term 'public economic enterprises' in reference to all enterprises set up by the state or public authorities to carry out business activities thereby avoiding the confusion arising from a particular definition of the term 'public enterprise'. As highlighted above, the scope of the term 'public enterprise' can extend to all public economic enterprises or it can be

\footnotetext{
${ }^{56}$ Proc . 25/1992Art. 19(1).

${ }^{57}$ Proc . 25/1992, Art 6(6).

${ }^{58}$ Proc . 25/1992, Art. 27.

${ }^{59}$ Proc . 25/1992, Art. 28.

${ }^{60}$ Proc . 25/1992, Art. 31.

${ }^{61}$ Proc . 25/1992, Art. 30.

62 Proc . 25/1992, Art. 32.
} 
limited to public enterprises 'proper' depending on the law one relies on. Apart from such legal conundrum, no clear-cut universal legal theory of the public economic enterprise has emerged so far. ${ }^{63}$ Moreover, the classification of public economic enterprises does not pursue a consistent pattern. In the Ethiopian context, current public economic enterprises are formed as enterprises, corporations or share companies.

The difference in the legal form (or designation) in which a public enterprise is established is expected to have impact on the autonomy of its management from the intervention of the government or other agencies. ${ }^{64}$ But this envisages express articulation of such variation in the features and autonomy of various forms of public enterprises. Currently, public economic enterprises are established as enterprise (Ethiopian Airlines Enterprise), a share company (Construction and Business Bank S.C) or a corporation (Ethiopian Sugar Corporation). However, there are no clear elements of demarcation that explain the selection of a specific form, and it is also difficult to identify the basic distinction between these different forms.

Essentially, the entities are subject to the same legal regime despite their variation in designation. In the absence of a policy or legal parameter in Ethiopia, we can resort to the experience of other countries. A study conducted on ten enterprises from different countries sheds doubt whether the choice of form results from any distinctive consideration, ${ }^{65}$ and the situation is not any different in Ethiopia.

\subsection{Departmental undertakings}

Historically, the expansion of activities of the government to economic activities was achieved through departmental undertakings. Through this model, a business activity was carried out as an integral part of the government itself. They were not established as independent legal entities; rather they were established by an executive decision as part of an existing state organ or an independent unit. Departmental undertakings did not have legal personality and their activities were not distinct from the regular function of the state. Thus, both administrative and business activities were carried out by a single entity as part of the state structure.

\footnotetext{
${ }^{63}$ Wolfgang Friedmann, "Governmental (Public) Enterprises", in Alfred Conard (ed.) International Encyclopedia of Comparative Law, Vol. XIII, p. 71.

${ }^{64}$ V.V. Ramanadham (1986), Public Enterprise Studies in Organizational Structure, (Franc Cass \& Co. Ltd.), p. 13.

${ }^{65}$ Ibid, p. 263.
} 
As a result of inclusion in the state structure, departmental undertakings shared many features with government organs. They were under a ministry which ultimately assumed the responsibility to manage them. Their employees were civil servants and their budget was part of the national budget. ${ }^{66}$ They were rather public enterprises run as a department of the government, organized, financed and controlled like any administrative agency ${ }^{67}$ They were subject to the accounting and audit systems applicable to other government departments.

For example, before the Ethiopian Electric Power Corporation was established as a corporation under Regulation No. 18/1997, it was organized as Ethiopian Electric Light and Power Authority in 1956. The corporation is engaged in the production, transmission, distribution and sale of electric energy to the public and undertakes any other lawful business incidental or appropriate thereto. ${ }^{68}$ It is indeed challenging to run business activity under the auspices an administrative organ which is incompatible with business operations. The first challenge relates to lack of autonomy because a departmental undertaking does not have the freedom required in efficient business operations. Second, a governmental department is exposed to unrestricted political influence emanating from its structure. It thus lacks flexibility due to bureaucratic delay in decision making. Such delays are, inter alia, attributable to undue intervention from civil servants and inadequate autonomy of professional management. In general, the structure and workings of a departmental undertaking is incompatible with the financial, logistics, production, operational and marketing requirements of a competitive business enterprise. ${ }^{69}$

\subsection{Corporations}

In US literature, the word 'corporation' merely represents a legal entity separate and distinct from its stockholders. The word mainly distinguishes the entity from partnerships. In the Ethiopian context, however, various public enterprises use the word 'corporation'. In the earlier years, there were countries where the designation of a public enterprise as a 'corporation' usually meant being "clothed with the power of government, but possessed

\footnotetext{
${ }^{66}$ Supra note 26, p. 103.

${ }^{67}$ Manikrant Kumar, Different Form of Public Enterprise.

$<$ http://www.scribd.com/doc/32031522/> (last accessed on 28/11/2014).

${ }^{68}<$ http://www.eepco.gov.et/corporationhistory.php $>$ (accessed on 29/4/2014 ).

${ }^{69}$ Supra note 67.
} 
with the flexibility and initiative of private enterprise."70 The choice of this form is basically driven by the need to cloak the entity with autonomy so as to reduce interference in its operation. It can operate basically as a private entity but at the same time it has support of the government. But this virtue of the corporation form is said to have become a fiction as the organizational autonomy of corporations have been severely diluted in many countries. ${ }^{71}$

One cannot easily figure out why an enterprise owned by the state is formed as a corporation. The term 'corporation' refers to a specific legal form of organization of persons and material resources, chartered by the state, for the purpose of conducting business. ${ }^{72}$ It is submitted that a corporation has four essential features, namely corporate body established by parliament, separate legal entity, government ownership and financial independence. ${ }^{73}$ Others add to this that employees are not civil servants. ${ }^{74}$

Under Ethiopian law, the essential features of corporations are shared by other public enterprises. They are established by regulation and are governed by Proclamation No. 25/1992 in the same manner as other public enterprises. It is, thus, imperative to inquire into their peculiarity which warrants their designation as corporations. Comparing the establishing regulations of corporations and other public enterprises, one can understand that they are crafted in line with Article 6 of Proclamation No. 25/1992.

In most establishment regulations, the corporation is empowered to issue bonds and borrow money from international financial sources. ${ }^{75}$ Even if it is a power consistently conferred on corporations, it cannot be concluded that all corporations or only those which are designated as such do have the

${ }^{70}$ Supra note 64, p. 14.

${ }^{71}$ Ibid, pp. 14-15.

72 Encyclopedia Britannica, $<$ http://www.britannica.com/EBchecked/topic/138409/corporation $>$ (accessed on 18/6/2014).

73 Dnyanesh Kumar, What are the different forms of public sector enterprises? $<$ http://www.preservearticles.com/2011092714116/what-are-the-different-formsof-public-sector-enterprises.html $>$ (Accessed: 18/6/2014); See also Supra note 67.

${ }^{74}$ H. Hanson (1955), Public Enterprise: A study of its Organization and Management in Various Countries (International Institute of Administrative Sciences), p. 20.

${ }^{75}$ See Art. 5(10) of Sugar Corporation Establishment Regulation No. 192/2010; Art. 5(7) of Ethiopian Electric Power Corporation Establishment Regulation No. 170/2009; See Art. 5(8) of Metals and Engineering corporation Establishment Regulation No. 183/2010. 
power to issue debt instruments. One can find enterprises which are not designated as corporations even if they have this power ${ }^{76}$ while there are corporations which are not empowered to do so. ${ }^{77}$

The usage of the word 'corporation' in relation with entities that hardly fall under public enterprises creates further ambiguities regarding their salient features. For example, the Ethiopian Broadcasting Corporation (EBC) is established under Proclamation No. 858/2014 to broadcast main and current issues happening in the country and abroad as well as educational and entertainment events on the radio, television and website. This is a commercial activity under Article 5(14) of the Commercial Code. However, it is not organized as a business entity but as "an autonomous government institution having legal personality and rendering public service. ${ }^{78}$ Although the public dimension of its function is explicit, the corporation does not have the characteristics which justify the classification of its activities as business undertakings. First, EBC does not operate based on its capital, and it rather has budget from public revenue, supportive budget and other sources. ${ }^{79}$ It is not necessarily expected to make profit as it benefits from annual budget allocation. Its employees are governed neither by the civil service law nor the labour law of the country. The House of peoples' Representatives is empowered to issue regulations for the administration of employees of the corporation. ${ }^{80}$

However, Ethiopian Broadcasting Corporation is subject to the same financial and procurement system as public enterprises. ${ }^{81}$ Its books of accounts and financial documents are audited annually by the auditor general. ${ }^{82}$ As it is not a public enterprise, its establishment proclamation makes selective reference to certain rules applicable to public enterprises. Hence, an entity which is not a public enterprise may, as in the case of EBC, be referred to as a corporation thereby causing more uncertainty regarding the use of the term.

${ }^{76}$ Art. 5(6) of Ethio-Telecom Establishment Regulation No. 197/2010.

77 Ethiopian Railway Corporation' Establishment Council of Ministers Regulation No. 141/2007.

78 Ethiopian Broadcasting Corporation Establishment Proclamation No. 858/2014, Federal Negarit Gazette, $20^{\text {th }}$ Year, No. 49, November 2014, Art. 3(1)

${ }^{79}$ Ibid, Art. 14.

${ }^{80}$ Ibid, Art. 17.

${ }^{81}$ Ibid, Art. 15.

${ }^{82}$ Ibid, Art. 16(2). 
Under Ethiopian law, the term public corporation does not represent a distinct legal form with its own attributes. Notionally, however, corporations are a response to the need for a distinct type of "industrial and commercial enterprises of a major and complex character conducted under the auspices and the financial responsibility of the state, or of other public authorities" which led to the development of a distinct type of public enterprise known as public corporation. ${ }^{83}$ It is with this understanding that the corporation form is opted. For instance, the transformation of the Ethiopian Electric Light and Power Authority to the Ethiopian Electric Power Corporation in 1997 was justified by the need to commercialize and decentralize the entity. ${ }^{84}$ But it remains to be examined whether the establishment of a public enterprise as a corporation has any legal import. Given that they are subject to the same governing law as other public enterprises and that one finds entities which are not purely commercial designated as a corporation, it can be concluded that those enterprises designated as corporation do not constitute a distinctive legal form or category.

\subsection{Share companies}

The law recognizes that the government has the option to set up a business firm in the form of a business organization which will be governed by the legal regime applicable to private enterprises. ${ }^{85}$ Hence, the government can establish a public enterprise and convert it to a business organization under the Commercial Code. It is maintained that public enterprises are companies established by law which must be subject to the same legal regime (under the Commercial Code) applicable to share companies. ${ }^{86}$ The basis of this view is the reference made to the Commercial Code under Proclamation No. $25 / 1992 .{ }^{87}$ In line with this contention, public enterprises are companies except that they are established by law. However, the entities are distinct not only because they are subject to separate legal regimes but also because they have their own peculiarities. Even if the law provides for the establishment of a public enterprise as a business organization, it is not specific about the form of business organization chosen out of the forms recognized under the Commercial Code.

\footnotetext{
${ }^{83}$ Supra note 64, p. 18.

${ }^{84}<$ http://www.eepco.gov.et/corporationhistory.php> accessed on 29/4/2014

${ }^{85}$ Proclamation no 25/1992, Art. 47(2)(a).

${ }^{86}$ Getahun Seifu, , Supra note 17, pp. 103 \& 109

${ }^{87}$ Ibid, p. 110.
} 
The question becomes palpable when we, for example, consider a decision of the Government to establish a share company it wholly owns. It is to be noted that Proclamation No. 146/1998 extends the scope of the term 'public enterprises' to entities which are deemed to be enterprises for the purpose of privatization. As discussed above, the purpose of stretching the meaning of the term 'public enterprise' (in spite of the definition set forth in Proclamation No. 25/1992) to accommodate organizations which are not strictly public enterprises was to streamline the privatization process. Accordingly, the law facilitates the conversion of public enterprises to share companies (as recognized under the Commercial Code).

These companies are vehicles of privatization which are employed to facilitate transfer of ownership to the private sector. It can be observed, however, that we have several such companies which remained in government ownership for a long time. At any rate, in the absence of a clearly declared intention, they cannot be considered as public enterprises in the strict sense of the term. This scheme was not meant to utilize the organizational form as a means of undertaking commercial activities by the state. Hence, the law merely came up with a temporary solution ${ }^{88}$ to address the anomaly created by the conversion.

The required quantum of holding in the capital of such company is not explicit so that it can be considered as a government owned or public company. It is maintained that in such companies the government owns at least $51 \%$ of the total shares. ${ }^{89}$ Although the Commercial Code governs a share company wholly owned by the Government, the enterprise is not subject to requirements which are incompatible with its nature such as minimum number of shareholders, ${ }^{90}$ valuation of contribution in kind, share ${ }^{91}$ general meeting of shareholders ${ }^{92}$, appointment of directors, ${ }^{93}$ and qualification shares ${ }^{94}$.

88 As can be clearly understood from article 3(4), they are applicable until the agency (now authority) starts transferring shares of the company.

${ }^{89}$ Supra note 74.

90 Art. 307(1) and 311 Com. C. According to article 5(4) (b) of Proc. No. 25/1992 directors are to be appointed by the supervising authority.

${ }^{91}$ Com . C, Art. 315.

92 The authorities given to the general meeting of shareholders is to be exercised by the Supervising Authority. But as there will be no meeting, the provisions governing shareholders meetings are not applicable. article 5(4)(a) of Proc. No. 25/1992.

93 Com . C, Art. 347.

${ }^{94}$ Com . C, Art. 349; See article 5(4)(c) of Proc. No. 25/1992. 


\section{The Raison d'être of Public Enterprises and Comparative Experience}

The share of public enterprises in the GDP of high income, middle-income and Least Developed countries is respectively $8 \%, 9 \%$ and $14 \%$ while their share in investment constitutes $13 \%, 17 \%$, and $28 \%$ respectively. ${ }^{95}$ The presence of public enterprises transcends all economic settings, and it can be observed that they have more significance in economies of developing countries.

It is crucial to examine the reason why states establish public economic enterprises irrespective of variation in political ideology and economic realities. For some scholars, public enterprises continue to be an enduring phenomenon in a society for two reasons: that the economic activity of a government is a function of its greatly increased responsibilities for the life and welfare of their citizens, and that the complexities of the industrial and commercial activities undertaken by the government demand some permanent legal and administrative structure. ${ }^{96}$

There are other reasons that may justify the decision to establish public enterprises. One of the reasons can be the need to correct market failure such as inadequate private supply of goods and services and improving competition. The second reason is altering the structure of pay-offs of the economy by redistributing the benefits received by particular individuals or groups. The other reason is facilitating long-term economic planning by which enterprises will have a developmental role. Finally, departure from capitalist economic policies based on certain versions of socialism can put important industries into government hands as public enterprises. ${ }^{97}$ The raison d'être for public enterprises thus varies depending upon the country, sector, epoch or other factor ${ }^{98}$ under consideration.

Numerous public enterprises were created in various countries particularly after World War II, to address market deficits and capital shortfall, promote economic development, reduce mass unemployment and/or ensure national control over the overall direction of the economy. In

\footnotetext{
${ }^{95}$ M. Adil Kahn, (2005), "Reinventing Public Enterprises " in Public Enterprises: Unresolved Challenges and New Opportunities, United Nations. p.4.

${ }^{96}$ Supra note 1, p. v-vi.

${ }^{97}$ Supra note 3, p. 2.

${ }^{98}$ See Reginald Herbold Green, "Public Directly Productive Units/Sectors in Africa and Political Economy", in Yash Ghai(ed.), Law in the Political Economy of Public Enterprises: African Perspective, (1977), p.139.
} 
the course of their operations, however, rising corruption, management inefficiencies, overstaffing, inflation and rising current account deficits indicated the downsides of public enterprises as key players in economic development. Consequently, large-scale privatization of public enterprises was undertaken in the 1980s and 1990s, with the vital support of multilateral financial institutions. ${ }^{99}$

This trend has again been revisited since 2000, because it was realized that the state can pursue policies that can address the downsides of public enterprises (without necessarily privatizing them) and, in effect, prudently play its critical role in investment and development. Hence, the philosophy of public enterprises has changed by relieving public enterprise policy from political ideology and blending it with effectiveness and efficiency toward meeting national needs and the satisfaction of the people's wellbeing. ${ }^{100}$

The debate whether public enterprises are vehicles of development or impede development is still underway. ${ }^{101}$ The recent global economic crisis has weakened the arguments against public enterprises and the pursuits of reducing the role of governments in the economy. It is contended that "when governments in the United States, the United Kingdom and others had to rescue gigantic mortgage corporations, huge banks and complex insurance firms regardless of the financial impact on the budget and the debt, it would seem a waste of time to explain why the State is sometimes forced to intervene in the market to save it from its own excesses". ${ }^{102}$

${ }^{99}$ Supra note at 95, p. 3.

100 Peter Harrold (2010) "Role of Public Sector Enterprises in Country Development", in (2010) Public Enterprise, Vol. 17, Nos. 1-4, p.12 Harrold insists that there is now no more market fundamentalism, not even in the United States which has found the necessity to become the effective owner of the two of the largest private institutions in the country, in insurance and in automobile manufacture. Molaba stresses that the recent financial crisis has once again demonstrated that markets are not holy cows. See Talent Molaba "The Role of Public Enterprises in a Country's Economic Development: The Case of South Africa's SOSs," in Public Enterprise, Vol. 17, Nos. 1-4, p. 23.

${ }^{101}$ Peter Harrold (2010) "Role of Public Sector Enterprises in Country Development", in (2010) Public Enterprise, Vol. 17, Nos. 1-4, p. 16.

102 Rubens Ricupero (2010), "The Role of Public Sector Enterprise in National Development", in (2010) Public Enterprise, Vol. 17, Nos. 1-4, p.6 He further argued that the near to three trillion dollar losses caused by the financial meltdown [since 2008], not to mention the anonymous suffering of millions of honest people who lost their jobs or homes or both, dwarf by far the total sum of all the debt piled up by public enterprises over decades in developing countries. 
Even if the economic crisis seems to have redeemed public enterprises, recent data indicate that "the performance of public enterprises has been shockingly bad". ${ }^{103}$ Yet, it is maintained that in the face of inefficiency, government control and lack of professionalism, the continued existence of public enterprises is justified by higher objectives of development of capital intensive sectors, balanced regional development, increasing employment opportunities, preventing concentration of economic power and research and development. ${ }^{104}$

Extremist political and economic theories which promoted absolute abstention of the $\operatorname{state}^{105}$ from economic interventions or the ones that supported excessive state control have been found to be imprudent. Current discourse on public enterprises rather focuses on the dominance (and not the overall exclusion) of one or the other sector and on the factors that determine how the balance can be struck. It is in the context of these issues that the role and scope of public intervention remains unsettled. The intervention can be in the form of policy-making, implementation and/or direct participation in production of goods and services through state-owned enterprises. With regard to the last alternative, the degree of government intervention constitutes the crux of the policy debate on public enterprises.

One of the factors to be taken into account in making the choice is the efficiency of a given enterprise form in the allocation and management of resources toward optimal productivity and competitiveness. In the absence of conclusive empirical evidence, the perception is that inefficiency is a general feature of public enterprises. ${ }^{106}$ This contention is buttressed by the absence (or inadequacy) of profit motive, financial incentive, lack of

103 State Capitalism in the Dock: The performance of state-owned enterprises has been shockingly bad, The Economist, Nov $22^{\text {nd }} 2014$.

104 Ibid., p. 9-12; P.K. Jain, Seema Gupta, Surendra S.Yadav (1914) Public Sector Enterprises in India: The Impact of Disinvestment and Self Obligation on Financial Performance (Springer India), p. 8.

${ }^{105}$ William J. Baulom, (1983) Toward A Theory of Public Enterprises, Atlantic Economic Conference, p.13 available at: $<$ pages.stern.nyu.edu/ wbaumol/TowardATheoryOfPublicEnterprise.pdf $>$.

106 The commonly held view is that private enterprises perform better than public enterprises. Most empirical studies support that this view. Several factors contribute for the inefficiency including multiplicity of objectives, lack of clearly defined targets, the structure of the market, lack of incentive and form of ownership. See for instance Loannis S. Vavourace, (1988) The Theory of Public Enterprises Restated, Annals of Public and Cooperative Economics, Vol, 59. Issue 3, p. 331. 
pressure to optimize returns, and immunity from competition and takeover which are considered to be hallmark of public enterprises. ${ }^{107}$

Privatization is deeply embedded in the ideological perception which considers the private sector as inherently superior to the public sector. ${ }^{108}$ When public ownership is viewed as inefficient, unresponsive, or as misallocation of public resources, privatization may be expected to provide corrections to these problems. ${ }^{109}$ Some even propose that privtization has a potentially high impact on poverty alleviation ${ }^{110}$ and argue that developing countries will benefit from the reduced role of public enterprises. Motivated by the evidence on the failures of state-owned enterprises, governments in more than 100 countries have undertaken privatization programs since the mid-1980s ${ }^{111}$ and many of them adopted the programmes as a solution to inefficiency of the enterprises. ${ }^{112}$

The arguments forwarded in favour of the superiority of private enterprises is that goods and services can be efficiently supplied by the private sector and the role of the state should be reduced and be limited to inherently public sector activities. On the other hand, however, even those who accept the substantive nature of performance reform do not always

${ }^{107}$ Baulom, supra note 105.

${ }^{108}$ Iram Khan,(2006) Public vs. Private Sector - An Examination of Neo-Liberal Ideology, P.1 available at ,<http://mpra.ub.uni-muenchen.de/13443/>; See also Mohammed Fatty Mahmoud (1992) Privatization: A Solution to Problems of Public Enterprises J. KAU: Econ. \& Adm., Vol. 5, p. 33 http://mpra.ub.unimuenchen.de/13443/

109 Berhanu Mengistu \& Elizabeth Vogel (2009): Public Perceptions of Privatization in Ethiopia: A Case for Public Good or Private Gain?, International Journal of Public Administration, Vol. 32, p. 681.

$<$ http://www.tandfonline.com/loi/lpad20> (last accessed on 8/13/2011)

${ }^{110}$ Fudzai Pamacheche and Baboucarr Koma, (2007) Privatization in Sub-Saharan Africa - An Essential Route to Poverty Alleviation, African Integration Review Volume 1, No. 2, p. 1, Available at

$<$ https://waleolusi.files.wordpress.com/2013/05/privatization-in-sub-saharanafrica-an-essential.pdf $>$.

111 Alberto Chong and Florencio López-de-Silanes, (2005) The truth about Privatization in Latin America in Alberto Chong and Florencio López-deSilanes (ed.) Privatization in Latin America Myths and reality (Stanford University press and The World Bank), pp. 2-3.

${ }^{112}$ Mohammed Fatty Mahmoud (1992) Privatization: A Solution to Problems of Public Enterprises J. KAU: Econ. \& Adm., Vol. 5, P. 4 Availabale at $<$ http://www.kau.edu.sa/files/320/researches/51536_21671.pdf $>$. 
suggest large scale privatization as a pragmatic and far-sighted choice. ${ }^{113}$ As a substitute solution to the inefficiency of public enterprises, some countries have embarked on corporatization and commercialization of public enterprises instead of privatizing them.

The appraoch in China to such enterprises is unique as its economy was transformed from central planing to China's version of state capitalism (labeled as socialism with Chinese characteristics). When the reform was initiated in 1978, public enterprises controlled the economy ${ }^{114}$ and communes dominated rural agriculture. Since the early 1990s, the role of the government has changed from mandatory planning of the economy to guideline plan setting or macro level regulation. ${ }^{115}$ The reform of stateowned enterprises is intended to liberate the companies from bureaucratic control that hinders their management rather than transferring them to private hands. ${ }^{116}$

Nigeria carried out a hybrid programme of privatization and commercialization of public enterprises because they are viewed as an important strategic tool for fostering rapid economic growth and development. $^{117}$ For South Africa, public enterprises are powerful instruments for achieving developmental goals because they are commercial

113 Yacob Halemariam and Berhanu Mengistu (1988), Public Enterprises and the Privatisation Thesis in the Third World, Third World Quarterly, Vol. 10, No. 4, p. 1585.

114 David Harvey, (2005) A Brief History of Neoliberalism, (OxfordUniversity Press), p. 125.

115 Seung-Wook Baek, (2005) Does China Follow "the East Asian Development Model"? Journal of Contemporary Asia, Vol. 35, No.4, p. 488.

116 Jonathan G. S. Koppell, (2007) Political Control for China's State-Owned Enterprises: Lessons from America's Experience with Hybrid Organizations, Policy Studies Organization, p. 255Available at:

$<$ http://works.bepress.com/jonathan_koppell/3 >; There those who question the success of the reform to improve performance of public enterprises of China using western laws without the withdrawal of the state from the economy or significant reduction of the ownership in public enterprises is doomed to fail. Guanghua Yu (2004), Using Western Law to Improve China's State-Owned Enterprises: Of Takeovers and Securities Fraud, 39 Valparaiso University Law Review, Vol. 39, No. 2, p. 339.

117 Afeikhena Jerome (2003), Public Enterprise Reform in Nigeria: Evidence from the Telecommunications Industry, African Economic Research Consortium, p.12 . 
entities with the task of achieving strategic national economic objectives. ${ }^{118}$ Public enterprises in India have been the most important strategic components of the economy. Over the years, they have facilitated balanced regional investment in addition to generating large surpluses and enabling the state to finance large developmental programmes. ${ }^{119}$ Various enterprises in Europe started as public enterprises to mainly reduce market failure. ${ }^{120}$ In developing countries, however, their emergence coincided with the initial stage of industrialization and economic development. The enterprises emerged as a necessary condition for development pursuits and as an economic tool. ${ }^{121}$

\section{Ethiopia's Laws on Public Enterprises: Role and Significance}

Generally, a public enterprise comes into being either through nationalization or through creation by government of an enterprise de novo or through government investment in a joint venture. ${ }^{122}$ In Ethiopia as well, the emergence of public sector enterprises coincided with the modernization of

118 Talent Molaba (2010) "The Role of Public Enterprises in a Country's Economic Development: The Case of South Africa's SOSs," in Public Enterprise, Vol. 17, Nos. 1-4, P. 21 In third world countries privatization was prescribed as a panacea for improving performance of public enterprises. See Supra note 112, p. 1565.

119 There are many regions in India where the private sector requires a very high level of incentives and other "concessions" in order to be induced to operate. The public sector has taken up these challenges and has taken the lead in bringing about balanced regional growth and development of industry in different parts of country. See Anil Chandy Ittyerah, (2010) "The Role of the public Sector Enterprise in the Indian Economy" in Public Enterprise, Vol. 17, Nos. 1-4, p. 29.

${ }^{120}$ Nevenka Hrovatin (2010) “ The Evolution and Role of Public Enterprises in the EU and Slovenia," in Public Enterprise, Vol. 17, Nos. 1-4, P. 24 Successful businesses in developed countries began as public enterprises. In France, for instance, Renault, Alcatel, EdF, Thomson, and Elf were state owned enterprises for a long time, as were Rolls-Royce and British Aerospace in the UK See P.K. Jain, Seema Gupta, Surendra S.Yadav (1914) Public Sector Enterprises in India: The Impact of Disinvestment and Self Obligation on Financial Performance( Springer India), p.8,

${ }^{121}$ Supra note 5, p. 77.

122 Id., p. 87. 
the state, measures of nationalization and arguably joint investment which can be challenged whether that gives rise to a public enterprise.

A close examination of the evolution of public enterprises in Ethiopia shows that a great number of the reasons discussed above have been invoked upon the establishment of public enterprises. The role of these enterprises in the country's economy is contingent upon the policy adopted by the government in a specific period of time. Their significance and mission vary with the policy of a particular government or even with the alteration of policy of a government.

During the imperial time, trade and industry had insignificant role in the national economy ${ }^{123}$ in addition to the fact that the social and economic situation could not justify government intervention. Even in the few cases where the government opted to have a role, ${ }^{124}$ conceptual distinction was not made between public enterprises and departmental undertakings. In fact, the concept and policy of public sector enterprise was non-existent. Of the few public enterprises during this era, Ethiopian National Corporation can be mentioned as the first parastatal entity which was set up in $1941 .{ }^{125}$

After the 1974 revolution, public enterprises were methods of promoting the socialist ideology and they were products of what is referred to as ideological commitment. ${ }^{126}$ The Dergue vowed to eradicate what it called "idolatry of personal gain" letting the private sector to engage in activities which were not harmful to the interest of the society so as to give preeminence to the interest of the community. ${ }^{127}$ Thus, economic activities were transferred to exclusive government ownership if the activities were exclusively reserved to the Government; or majority shares were transferred if they were to be carried out jointly by the government and a foreign investor. ${ }^{128}$ Consequently, at the end of the 1970 s, two hundred large public

${ }^{123}$ Trade constituted 7\% of the gross domestic product and industry's share was much less than that. See Bahru Zewde, A History of Modern Ethiopia (18551991)( $2^{\text {nd }}$ Ed) (2002), p. 196.

124 The Awash Valley Authority was established in 1961 under which agricultural, agro-industrial, hydroelectric enterprises were operating. See Id, p. 194.

125 Supra note 123, p. 197.

${ }^{126}$ See the discussion in John Nellis, Back to the Future for African Infrastructure? Why State-Ownership Is No More Promising the Second Time Around Center for Global Development, Working Paper Number 84 February 2006, p. 6, $<$ http://www.cgdev.org/files/6352_file_WP_84.pdf> (accessed on 8/8/2014).

127 Preamble, Government Ownership and Control of the Means of Production Proclamation No. 26/1975, (Negarit Gazeta 34 ${ }^{\text {th }}$, year, No. 22, March 11, 1975).

${ }^{128}$ Id., Arts. 3 and 6. 
enterprises were operational which accounted for $20 \%$ of the country's economy. $^{129}$

The principle that means of production and distribution should remain in the hands of the government was realized through public enterprises significantly diminishing the role of the private sector. Public enterprises were organized in accordance with Public Enterprises Proclamation No. 20/1975. ${ }^{130}$ The proclamation was enacted to bring all matters relating to the coordination and operation of public enterprises under the overall direction of a responsible Minister. ${ }^{131}$ The Ministry of Natural Resources Development was empowered to establish and confer legal personality on public enterprises to engage in agricultural, industrial, commercial, public service, hotel, tourist service and mining activities. ${ }^{132}$ It remained the main form of carrying out economic activities in the country until 1990. Public

${ }^{129}$ Forbes Global Magazine, <http://www.winne.com/ethiopia/to07.html $>$ (accessed on $07 / 08 / 2014$ ).

${ }^{130}$ At an earlier stage the following public enterprises were legally formed: National Textile, Ethiopian Printing, Ethiopian Food, National Metal, Ethiopian Liqueurs, Leather and Shoe, Fiber Works, Ethiopian Salts, National Soap, Ethiopian Building Materials, Rift Valley Agricultural Development, Harerge Agricultural Development, National Transport etc. In the meantime when the ministries were reformulated by a new proclamation, the Ministry of National Resources Development phased out and the public enterprises under it were transferred to the concerned ministries. According to the new proclamation, public enterprises were reorganized under Industry, Agriculture and Resettlement and Transport and Communication Ministries. The second Proclamation No.142/1978 established State Farms Development Authority under the Ministry of Agriculture and Resettlement. The Authority was established with the intent of management of the state farms in a centralized organization. As it is stated above, the structural set up of public enterprises was undergoing various changes and new companies were established in the process. See Aweke Tenaw, (2011) The Performance of Privatized Public Enterprises in Ethiopia: The Case of Hotel Enterprises, unpublished, Addis Ababa University School of Graduate Studies, pp. 12-13.

131 Preamble Public Enterprises Proclamation No. 19/1975, (Negarit Gazeta $34^{\text {th }}$ year, No. 15 February 4, 1975).

132 Proc. No 20/1975 Article 3; Prior to the economic reform, public enterprises were organized in accordance with public enterprises proclamation N0.20/1975, N0.131/1978 and Public Enterprises Regulation No.5/1975, Agricultural Development Corporations Regulations N0.60/1978 and the regulation and coordination of Public Financial Operations Proclamation No. 163/1979. 
Enterprises Proclamation No. 20/1975 governed public enterprises until it was repealed by Proclamation No. 25/1992. ${ }^{133}$

With the change of policy following the demise of the Derg, public enterprise reform was launched requiring these enterprises to operate on a competitive basis in a free market setting competing with private firms. This policy shift reduced the part played by public enterprises ${ }^{134}$ in the economy and eliminated the special privilege accorded to them. The reform introduced privatization of enterprises except those which remained under the government ownership. As a tool of implimenting this policy, a new public enterprises law was enacted which provided for supervising authority and management board of the enterprises that has full autonomy. ${ }^{135}$

Ethiopia's post-1991 policy on public enterprises can be characterized as kaleidoscopic as there is shift of policies ranging from restructuring and privatization to the mushrooming of public enterprises. Almost all relevant laws declare that public enterprises should operate in a competitive environment. More specifically, the pledge in the laws, for example, expresses the necessity to change the role and participation of the state in the

133 Proc No 25/1992 article 3(1)(a), The legal regime applied during this period encompasses Proclamation No.131/1978 and Public Enterprises Regulation No.5/1975, Agricultural Development Corporations regulations No.60/1978 and the regulation and coordination of public Financial Operations Proclamation No. $163 / 1979$.

${ }^{134}$ In fact, it is submitted that the demise or rather the decline in the dominance of the public enterprise in the economy in most African countries started with the introduction of Structural Adjustment Programs (SAPs) in the 1980s. Kauzya John-Mary, The Question of the Public Enterprise and Africa's Development Challenge: a Governance and Leadership Perspective, p. 3, Paper presented during the Ad hoc Expert Group Meeting on "Re-inventing Public Enterprises" held in New York from 27 to 28 October 2005, available at

< http:/unpan1.un.org/intradoc/groups/public/documents/un/unpan021612.pdf>, (accessed on 07/08/2014).

135 In the course implementing the new policy, in addition to preparing the ground work for restructuring and privatization, it is stated that several actions were taken to address problematic enterprises such as liquidation of Ethiopian Building Construction Authority, amalgamation of Ethiopian Domestic Distribution Corporation, Ethiopian Import Export Corporation, issuance of regulations to restructure and establish public enterprises. Mekonnen Manyazewal, "The Macroeconomic Policy Environment and Public Enterprise Reform in Ethiopia" in Abudulhamid Bedri Kello (ed.), Privatization and Public Enterprise Reform in Ethiopia (1993), pp. 101-105. 
economy and the need to encourage the expansion of the private sector. ${ }^{136}$ On the other hand, the policy documents issued by the ruling party underscore that one of the two reasons which validate a developmental state policy in Ethiopia is the rectification of market imperfections by effectively intervening in selected sectors. ${ }^{137}$ According to the policy, this can be achieved through a big government ${ }^{138}$ which justifies the size of government and dominance of the public sector.

Even though the laws in force express their objectives toward reducing the participation of the government in the economy, we can witness the establishment of mega public enterprises whose place in the economy can be easily felt. This appears to be a mirror image of the dilemma the World Bank has, at different times, encountered in this respect:

World Bank and its approach to public enterprises swung as much as any perhaps. We were strong supporters in the sixties and seventies of their creation and of heavy investment programs both in infrastructure and also, of course, in industry. From the mid eighties to the end of the nineties we were among the great advocates for privatization, but more than that; in the case of infrastructure, there was a belief that the all state needed to do was to get the policy right, and private investment would

${ }_{136}^{136}$ Preamble, Proc No. 412/2004.

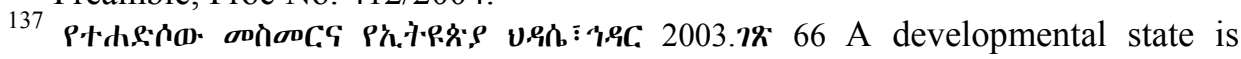
interventionist. But it is submitted that it does not suffice to state that a developmental state is an interventionist state for it intervenes as a capitalist state and not as a socialist state. The reasons for such interventions are the ones that determine whether a state is either developmental or not. A developmental state is distinguished from other types of states because of the nexus between its ideological and structural components. Accordingly, it has a mission of ensuring economic development and building capacity to implement economic policies. It is a state which is able to set developmental goals, create and sustain a policy climate and an institutional structure that promotes development. See Development and Transformation: The Place of State -Owned Enterprises in A Developmental State, available at

$<$ http://www.thepresidency.gov.za/electronicreport/volume_4.html $>$, (accessed on $24 / 11 / 2014)$; On the other hand it is contended that even though it is necessary that the government must intervene in areas markets 'fail', the countless cases of unsuccessful intervention suggest the need for caution. Markets fail, but so do governments. To justify intervention it is not enough to know that the market is failing; it is also necessary to be confident that the government can do better.

See World Development Report of 1991, available at:

$<$ www.rrojasdatabank.info/wdr1991 toc.htm >, ( accessed on 24/11/2014).

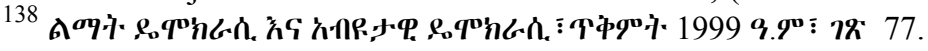


follow to meet all needs. Since 2000, the realization that this was naive has grown and that the correctly played role of the state is beyond getting the policy right, and that the role of the state in investment and development was critical. ${ }^{139}$

Ethiopia's economic policies during the past twenty years indicate change of role and significance of public enterprises. The ambivalence of the state regarding its role in the economy can be inferred from the privatization effort, on the one hand and retaining the big enterprises and the burgeoning of new ones, on the other. The policy alluded to in the various laws expresses the desire of the government to pull out of the economic sector so long as the market is viable. For example, Proclamation No. 25/1992 envisions broader private sector with reduced number of public enterprises which compete with the private sector. With a view to ensuring the increasing share of the private sector in the economy, several laws were enacted in order to address the need to change the role and participation of the state in the economy and to encourage the expansion of the private sector. ${ }^{140}$

On the other hand, starting from the adoption of developmental state economic model, several public enterprises have been formed and are being formed side by side with tiptoeing privatization. The Government's developmental state policy confers an activist role on the state in addressing market failures by filling gaps in areas where adequate private sector supply response and capacity is lacking. ${ }^{141}$ Consequently, mammoth enterprises are set up by the state, in almost every sector of the economy, from trade to engineering.

The significance of investment in public enterprises can be explained by the contribution required of public enterprises toward the realization of the Growth and Transformation Plan (GTP). ${ }^{142}$ Assessment of Ethiopia's

139 Supra note 100 , p. 12.

${ }^{140}$ Proclamation No. 146/1998 and 412/2004, Preamble.

141 African Development Bank Group, Federal Democratic Republic of Ethiopia Country Strategy Paper (2011-2015), p. 5.

$<$ http://www.afdb.org/fileadmin/uploads/afdb/Documents/Project-andOperations/Ethiopia-2011-2015\%20CSP\%20ENG1.pdf $>$ (last accessed on 28/11/2014).

142 Currently Ethiopia has gone a long way in implementing the five year Growth and Transformation Plan (GTP) which is ambitious. The total investment required for GTP is estimated at ETB 1.26 trillion (US\$77 billion) $45.1 \%$ of which will be contributed by state enterprises. See African Development Bank 
economy shows that the public sector is expanding. The growing activities of state enterprises is best "captured by the five-fold rise in their borrowing from the banking system, which is up from Birr 8 billion about five years ago to an estimated Birr 42 billion in 2010/11 fiscal year, and roughly twothirds of all banking system credit is now directed to the public sector". ${ }^{43}$ Of the nearly 45 billion Birr credit extended in the year beginning June $2012,83 \%$ went to finance state enterprises. ${ }^{144}$

Group, Federal Democratic Republic of Ethiopia Country Strategy Paper 20112015 (April 2011) Page 9-10,See also IMF Country Report No. 12/287, October 2012, International Monetary Fund, pp. 6-9.

143 Ethiopia: Macroeconomic Handbook 2011/2012, Access Capital, 2011, page 5966. Ethiopia currently has an incredibly vast asset base of over one hundred state-owned enterprises and companies built up over a period of several decades. This asset base was largely built up in prior governments, either through nationalization of previously private properties or as green-field projects established in the context of a socialist-oriented economic regime. The asset base of companies under the public sector includes a world renown airline, a commercial bank with 300-plus branches, an insurance company, a large shipping company, a telecom company, chemical industries, mining factories, cement factories, metal works factories, pharmaceutical factories, coffee plantations, wineries, flour factories, shoe factories, hotels, and (until recently) even several beer factories and a spa. Based on 2009/10 data, access capital, p. 64.

${ }^{144}$ Fortune Addis, Vol. 14 , NO 706, November 12, 2013, $<$ http://addisfortune.net/articles/imf-calls-govt-to-phase-out-nbe-bill-on-privatebanks/> (accessed on November 12, 2013); IMF Country Report No. 12/287, October 2012, International Monetary Fund, p. 4. Presently the private sector is complaining that it is overcrowded and some are recommending to carefully consider the balance between public and private sectors in the economy. See S. Kal Wajid, the head of the IMF mission said it would be important to foster competition in areas where public enterprises enjoy monopolies, and gradually withdrawing from sectors where they crowd out the private sector, $<$ http://www.africareview.com/Business---Finance/Open-up-IMF-urgesEthiopia/-/979184/1906092/-/of9r8p/-/index.html $>$ (accessed on 01/11/2013) The share of public sector enterprises is so immense that, some concerns are aired whether it is sustainble. IMF Staff Mission observed that:

Ethiopia's public sector led development strategy has delivered robust growth and rising living standards but is now at cross roads. To sustain growth and employment creation, there is a need to carefully consider the balance between public and private sectors in the economy. A vibrant private sector is essential to attain middle income status. Therefore, it would be important to foster competition in areas where public enterprises enjoy 
In line with the current trend which enhances the role of public enterprises in the political system, the following observations were made (in the context of another country) regarding the potential impact of economic dominance by public enterprises:

These agencies [government economic enterprises] increasingly monopolize and allocate public resources, provide critical services and control access to them, create a large sector of wage-employment, regulate prices, and otherwise make decisions affecting economic development, the quality of generally and the interests of individuals. They may constitute a large new branch of government (and source of power), which have not been adequately examined by political, social, and legal theory and which operates within inadequate legal frameworks. ${ }^{145}$

In spite of caveats against excessive state involvement in economic activities, the sustained significance of public enterprises can be witnessed. This is so, despite the contention on the extent to which investment should be made by the public sector in general or through public enterprises in particular. ${ }^{146}$ The facts on the ground indicate that the sector is and remains to be vital for the country. ${ }^{147}$

monopolies, and gradually withdrawing from sectors where they crowd out the private sector.

See statement by an IMF Staff Mission on the 2013 Article IV Consultation

with Ethiopia, Press Release No. 13/247, July 4, 201,

$<$ http://www.imf.org/external/np/sec/pr/2013/pr13247.htm>.

145 Supra note 1, p. vi.

${ }^{146}$ Some argue that even though the economic crisis in the west improved the place of public enterprises in the economy, the danger now is not so much from market fundamentalism but from State fundamentalism. In the wreckage of so many grievous mistakes of the pre-crisis era - the belief on the alleged selfregulatory capacity of markets, of the infallible superiority of private firms over public companies in all cases and under every imaginable situation - we run the opposite risk of turning back the clock to the idealization of the public sector and to the idolatry of the State. Rubens Ricupero "The Role of Public Enterprise in National Development" in Štefan Bogdan Šalej (ed.), Public Enterprise, 2010, Vol. 17, Nos. 1-4, p. 7.

147 In fact one of the considerations that governments must take into their development plans is the optimum mix of public sector, private sector and mixed sector. Supra note 1, p.18; In response to the ever increasing dominance of public enterprises, voices are heard agianst the expansion of public sector entrprises one of which goes as "breeding public enterprises cannot help to realise the envisioned growth, as the state has its own limitations. Besides, 


\section{Conclusion}

State or public ownership is a very important factor in determining state ownership even though there is no consensus on the quantum of investment which renders an enterprise public. Recent Ethiopian laws include those enterprises in which the government invests partially thereby deviating from the earlier approach which required total ownership by the state. Partial investment can range from $99 \%$ to $1 \%$ and it is not certain whether it can be said that the public has stake in enterprises where the share of the government or public authorities is nominal. It is, therefore necessary to rectify the piecemeal approach to the definition of public enterprises by undertaking a holistic approach to the issue and by coherently stipulating the core attributes of a public enterprise in Ethiopia.

As highlighted in the preceding sections, the application of some laws depends on the determination of the scope of the term, 'public enterprise'. This is more so in criminal laws which may render officers of such enterprises criminally liable (under specific laws as in the case of corruption) contingent upon the classification of an entity into a public enterprise. In those laws it is simply stated that partial investment is enough to make an enterprise public. Another challenge that needs to be addressed relates to gaps in the law. A case in point in this regard is the federal system which has resulted in the establishment of enterprises by the regional states. These enterprises are not accommodated in the existing legal framework and questions pertaining regional state enterprises are not answered because of the legal lacuna. ${ }^{148}$

With regard to form, we find entities which are organized in the form of a share company and governed under the Commercial Code while they are also considered as public enterprises. It follows that strictly speaking, the organizational form of the entity does not necessarily determine the type of enterprise. One of the elements unique to public enterprises is that they are subject to a special legal regime because of the peculiarity of the enterprise. But, some of these laws, as observed in the preceding sections, include entities which are not governed by the special law under consideration.

public ownership of profitable enterprises entails so much inefficiency and hence sets the economy to settle for lower productivity levels". Addis Fortune, September 7, 2014 [ Vol 15 , No 749] <http://addisfortune.net/columns/breedingpublic-enterprises-no-fix-for-market-failures/ $>$.

For example, are regional state enterprises subject to the bankruptcy regime under the Commercial Code? 
Considering the importance of public enterprises and their role in the economy, conceptual clarity is indeed necessary. There are various practical implications that can emanate from the ambiguities and inconsistencies in the concept and characteristic of public enterprise. Such implications include the ambiguities that would be created in relation with the scope of power of some government organs such as the Auditor General or Parliament because some functions of these public entities in relation to the enterprises is contingent upon the definition of 'public enterprise'. When preference is accorded to the enterprises (or their officers) or when they are made subject to or exempted from regulatory measures, it is imperative to determine which enterprises fall under the classification. The proactive development and revision of policies, strategies and plans that relate to economic entities inevitably presuppose clear taxonomic categories. It is, thus, crucial to come up with a refined, clear and holistic conception of 'public enterprise' in order to address the legal and practical concerns in delimiting the boundary of the term and the organizational form of the entity. 